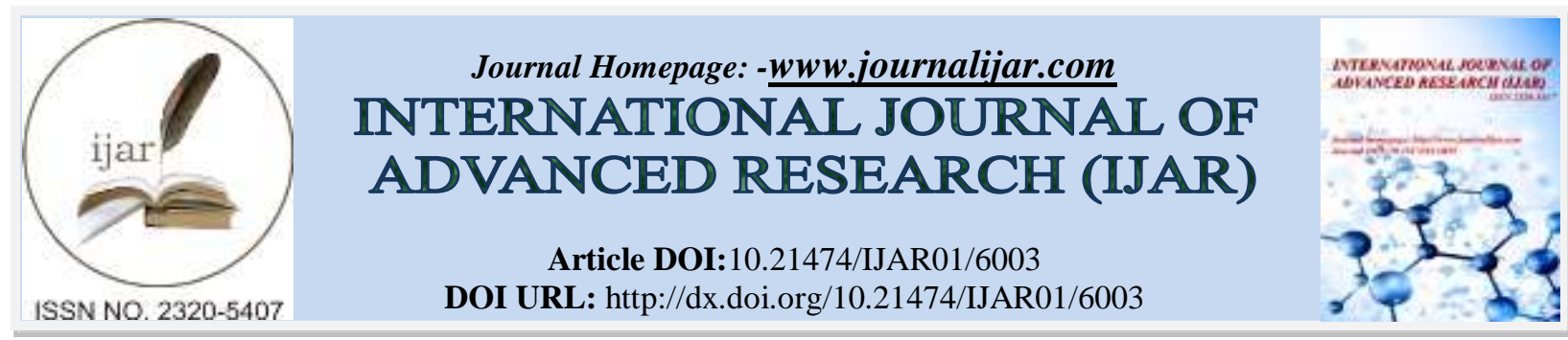

RESEARCH ARTICLE

\title{
TRAINING AND DEVELOPMENT - AN EFFECTIVE INSTRUMENT FOR PERFORMANCE ENHANCEMENT.
}

\author{
Rajwinder Kaur ${ }^{1}$ and Dr. Dalvinder Singh Grewal ${ }^{2}$. \\ 1. Research Scholar, IKGPTU, Kapurthala (PUNJAB). \\ 2. Professor, Desh Bhagat University, Mandi Gobindgarh (PUNJAB).
}

\section{Manuscript Info}

Manuscript History

Received: 08 October 2017

Final Accepted: 10 November 2017

Published: December 2017

Key words:-

Training, Development, Human

Resource Management, Benefits .

\begin{abstract}
Training and Development is an emerging concept in the wide field of Human Resource Management (HRM). In this era of cut-throat competition and the changing scenario of business, training and development becomes an inseparable part of HRM. Training effort is one of the useful litmus test to judge the reality of the adoption of the HRM policies in the organization. Training is the method of learning new things through education, practice and experience. Training is like an investment in Human resource with a promise that they can give better returns in future. An effective training can make the employees more competent and efficient and contribute to the growth of the organization. Training makes the employees more versatile in operations. In this study an attempt has been made to analyze the benefits of employee training and development. For this purpose, an emphases relay on to explore the benefits of training and development at different levels. To meet this purpose, a proposed model was prepared to establish the relation between the training and development benefits and with the employee performance.
\end{abstract}

Copy Right, IJAR, 2017,. All rights reserved.

\section{Introduction:-}

The Concept of Training and Development:-

Training is the formal and systematic modification of behaviour through learning which occurs as a result of education, instruction, development and planned experience (Armstrong). Training program acts as a catalyst to enhance the performance of the employees. Training is a necessity and not a luxury. Organizations spend a huge amount on training for the betterment of their employees. Training is about personal and professional growth and shouldn't be taken as a punishment or something which is only given to employees who are not up to scratch. Instead, why not treat it as a reward for your best employees. Training provides the opportunity to raise the profile development activities in the organization.

1. Michael Jucius:-defined training as "a process by which the aptitudes, skills and abilities of employees to perform specific jobs, are increased".

2. Drucker:- defined training as a "Systematic process of altering the behavior and/or attitude of employees in a direction to achieve organizational goals".

3. David and Stephen:- described training as "A learning experience in that it seeks a relatively permanent change in an individual that will improve his or her ability to perform on the job". 
Development actually refers to the process by which the executives acquire not only skills and competence to do their present jobs but also capabilities to tackle/handle future managerial tasks. Development is any learning activity, which is directed towards future, needs rather than present needs, and which is concerned more with career growth than immediate performance.

1. According to Koontz and Donnell, "Management development concerns the means by which a person cultivates those skills which will improve the efficiency and effectiveness with which the anticipated results of a particular organizational segment are achieved."

2. According to Flippo, "Management development includes the processes by which the managers and executives acquire not only skills and competency in their present jobs but also capacities for future managerial tasks."

3. According to Dale S. Beach, "Management development is a systematic process of training and growth by which individuals gain and apply knowledge, skills, insights and attitudes to manage orientation effectively."

Difference between training and development:-

\begin{tabular}{|c|l|l|}
\hline Learning Dimensions & \multicolumn{1}{|c|}{ Training } & \multicolumn{1}{c|}{ Development } \\
\hline Nature & Training is an event & Development is a continuous process \\
\hline Focus on & Present & Future \\
\hline Teed & $\begin{array}{l}\text { Training need = job requirement - } \\
\text { existing competencies }\end{array}$ & $\begin{array}{l}\text { Development need = desired group } \\
\text { dynamism - existing attitude of values. }\end{array}$ \\
\hline Objective & Short term & Long term \\
\hline Motivation & $\begin{array}{l}\text { To improve the work performance of } \\
\text { the employees }\end{array}$ & To prepare employees for future challenges \\
\hline Aim & Trainer & Self \\
\hline Orientation & Specific job or role related & Conceptual and General knowledge \\
\hline Growth Opportunity & Enhancement of a particular job skill. & $\begin{array}{l}\text { Pareer oriented } \\
\text { personality. }\end{array}$ \\
\hline Evaluation & Essential & Not possible \\
\hline
\end{tabular}

\section{Review of Literature:-}

Literature Review of this research paper is segregated into three sections enlisted as under:

1. Contribution of various authors towards training and development

2. Approaches to training

3. Historical development of training and development

\section{Contribution of various authors towards training and development:-} Oribabor (2000):-

Said that training and development aim at developing competencies such as technical, human, conceptual and managerial for the furtherance of individual and organization growth.

According to Tan et al., (2003):-

Companies are making huge investment on training programs to prepare them for future needs. The researchers and practitioners have constantly emphasized on the importance of training due to its role and investment.

\section{According to Mukherjee (2007):-}

Organizations cannot survive without training and development of employees. Improvement in skills increases versatility and adaptability of employees that leads to required performance level in the current job.

Bates et al., (2010):-

Stated that usefulness of training program is possible only when the trainee is able to practice the theoretical aspects learned in training program in actual work environment. They highlighted the use of role playing, cases, simulation, mediated exercises and computer based learning to provide exposure to a current and relevant body of knowledge and real world situations. 


\section{Hussain (2011):-}

Carried out an empirical study of the relationship between motivation to transfer and transfer of training on job. The purpose of this paper is to highlight the effect of motivation to transfer on training effectiveness. This paper highlighted that transfer of training can be maximized through increasing motivation and enthusiasm in trainees to apply their knowledge and skill at their workplace.

\section{Farooq and Khan (2011):-}

Studied the impact of training and feedback on increasing the performance of employees. They stated that training is a catalyst for employees' performance improvement. They also concluded that training and feedback can increase the performance level of all sorts of the organizations; moving either separately or together training and feedback play their role in achieving organizational targets by making its employees more work focus and goal oriented.

\section{Kulkarni (2013):-}

Carried out a literature review on training \& Development and quality of work life.According to this review paper the major areas where employees are normally trained in an organization are Soft- skill Development, Personality Development, Interpersonal Relationship, Problem solving techniques, Managerial and Supervisory Training Program, quality improvement programs, technical processes, quality circle programs, Time management skills, employee efficiency development programs, violence prevention programs, regulatory compliances, goal setting and implementation of programs, workplace safety management, workplace communication, and so on.

\section{Omar (2015):-}

A positive relationship exists between training and organizational performance as an indicated that training sessions are working smooth in the services sector and it is enhancing organizational performance.

\section{Approaches to training:-}

According to (Rama, Etling, \& Bowen, 1993)-There are three approaches to training:

1. Traditional approach: the training staff designs the objectives, contents, teaching techniques, assignments, lesson plans, motivation, tests, and evaluation. The focus in this model is intervention by the training staff.

2. Experiential approach: the trainer incorporates experiences where in the learner becomes active and influences the training process. Unlike the academic approach inherent in the traditional model, experiential training emphasizes real or simulated situations in which the trainees will eventually operate. In this model, the objectives and other elements of training are jointly determined by the trainers and trainees. Trainers primarily serve as facilitators, catalysts, or resource persons.

3. Performance-based approach: goals are measured through attainment of a given level of proficiency instead of passing grades of the trainees. Emphasis is given to acquiring specific observable skills for a task.

\section{Historical Development of Training and Development:- \\ Tracing the roots of Training and development:-}

The history of training and development was as old as the history of man on earth. As history evolved, various training and development methods were used in over a period of time depending on the dynamism of the business environment. But then, there was no full time training of employees.

1. Greek Philosophy:-In 300BC, Socrates (470-399BC) engaged his learners by asking questions (now known as the Socratic or dialectic method). He often insisted that he really knew nothing, but his questioning skills allowed others to learn by self-generated understanding."Excellence is an art won by training and habituation." - Aristotle

\section{Middle Ages:- Apprenticeship:}

Some children were apprenticed to craftsmen who had the specialized skills and tools for a particular trade. In exchange for work, the craftsman would teach the child the craft at which he was an expert. The norm for apprentices was to live with the master and receive practically no pay, except maintenance and training.

\section{Scholasticism:}

Is one of the fore-runners of experiential learning or learner-based instruction as once the information has been presented, then the learners have to use various methods to judge and arrive at the real meaning of the evidence. 
The Prussians started to apply gaming situations to military training during the 1800s. The games consisted of detailed maps and different colored blocks to represent troops. After the games, the player's decisions on troop placement and appropriate armaments were and critiqued.

\section{The Industrial Revolution:-}

The Classroom: In the 1800s factory schools were created, in which workers were trained in classrooms within the factory walls. In 1872 Hoe and Company, a manufacturer of printing presses in New York City, had such a volume of business that it was necessary to establish a factory school to train machinists. The old-style apprentice system was inadequate.

\section{Vestibule Training:}

A vestibule is a large entrance or reception room or area. Vestibule training is a term for near-the-job training, as it offers access to something new (learning). A classroom or training room, located as close as conditions permit to the department for which the worker is being trained, is furnished with the same machines as are used in production. There are six to ten workers per trainer, who is skilled worker or supervisor from the company.

\section{World War I:-}

\section{Systematic Training: Show, Tell, Do and Check}

To solve an urgent need to train shipyard workers in 1917, Charles R. Allen created the "Show, Tell, Do, and Check" method of job instruction.

\section{World War II:-}

Systematic Training: JIT (Job Instruction Training):

During World War II, the need for a method of fast and efficient training becomes urgent. Training within industry, an advisory service formed by the national defense advisory commission, developed the systematic on-the-job training method called JIT.

\section{Role Playing:}

Dr .J.L. Moreno designed the first known role playing techniques in 1910; however, it did not become widely known or used until he moved from Vienna, Austria to the United States in the 1930s.

\section{After World War II:- Individualized Instruction:}

Individualized instruction in essence replaces the teacher with systematic or programmed materials. Programmed materials are instruction that has been divided into small steps which are easily understood by the learner. After each step is required an active response by the learner in the form of answering a question, drawing a graph, solving a problem and so on.

\section{The End of $20^{\text {th }}$ Century:-}

The different strategies followed by various organizations for their business excellence.

Job Support: Job support is a form of training that does not require the workers to learn, but simply to know where to find the changing information they need.

\section{Industry Profile:-}

Ludhiana occupies a vital position in the industrial scenario of Punjab and even India. It is even called the industrial capital of Punjab. The industries are engaged in the production of bicycle and its components, sewing machines and parts of machines, ready-made garments, and hosiery goods. Hero Cycles Limited based in Ludhiana. Hero's colossal journey started before independence. Hero, the brand name symbolizing the steely ambition of the Munjal brothers, came into being in the year 1956. From a modest manufacturer of bicycle components in the early 1940's to the world's largest bicycle manufacturer today, the odyssey was fuelled by one vision - to build long-lasting relationships with everyone, including workers, dealers and vendors. Today, Hero Cycles is the one of the world's largest manufacturer of Bicycles and producing 19,000 cycles per day. The Company has fully equipped in-house R \& D facilities. The company has over 250 suppliers network, approx. 2800 dealerships \& over 4,300 employees and moreover ISO 9001 \& ISO 14001 certification from BVC of UK and recognized R\&D department by the Govt. of India. Mr. PankajMunjal, Co-Chairman and Managing Director of Hero Cycles, India's largest cycle manufacturer, 
has been appointed as the Chairman of Punjab Skill Development Board; a new initiative by the State Government to impart training to the large untrained workforce of Punjab.

\section{Major Achievements:-}

1. Hero Cycles was ranked 3rd amongst top Indian companies Review 2000 - Asia's leading companies award (2003) by Far Eastern Economic Review.

2. Hero Cycles is the World's largest manufacturer of Bicycles with record annual sales volume of over 5.6 million cycles in 2011.

3. Hero Cycles Limited is a Guinness Book Record holder since 1986 as the world's largest manufacturer of bicycles, with annual sales volume of 5.2 million bicycles in FY 2004.

4. Engineering Exports Promotion Council has awarded Hero Cycles with the Best Exporter Award for the last 28 years in succession.

Major Contribution of Hero Cycles towards T\&D:-

1. Hero Cycle Skill Development Center is a world class skill development and training center in Ludhiana, which was launched in 2013. It is a decisive step in improving the skill development of youth of the Punjab.

2. They have launched vocational skill development center 'Hunar' at Hero Cycles Limited, where the poor can get training for employment.

3. They also established computer training and learning cemtre in partnership with Microsoft.

4. Raman Kant Munjal Foundation also runs ASHA an educational programme for village children who are first generation learners.

5. Raman Munjal Vidya Mandir organizes recreational activities, soft skill training, personality development and regular get together with employees time to time.

\section{Statement of the Research Problem:-}

The problem of the study concentrated on analysis of the training and development programs conducted at the Hero Cycles Ltd., Ludhiana. The problem of the study is to identify the impact of various training components (stages of training process, organization policies and procedure, knowledge of trainer, evaluation system, willing trainee, training cost, training programs, nature of the training, training policy and training needs etc.) on various factors (like organization performance, productivity, employee performance, quality and quantity of products and services etc.) in the Hero Cycles Ltd.

\section{Objective of the Study:-}

The general objective of the study is to analyze the correlation between the training and employee performance. While the specific objectives are:

1. To analyze the importance and benefits of training and development in the organization.

2. To examine the historical roots of the training and development.

3. To examine the attitude of employees towards training.

\section{Significance of the study:-}

The study will create awareness about the importance of training and development in the organization. The study becomes necessary because many organizations now-a-days are striving to gain competitive advantage and there is no shortcut path to achieve it. The study helps to find out the attitude of employees towards training. However, the study results will help the management to determine the areas of improvement. It also helps to analyze how training and development enhance employee as well as organization performance. Furthermore, this research would give another chance to researchers to conduct research into training and development a framework for further research.

\section{Research Methodology:-}

Population of the study:-

The target population for the research work is the employees of the Hero Cycles in Ludhiana.

Research Design:- The present research is of descriptive in nature.

Instrument of data collection :-

The instrument used for collecting the data was structured questionnaire. 


\section{Sources of Data collection:-}

Primary data:-

Primary data collected through personal interview and structured questionnaire.

Secondary data :- The secondary data includes company record, literature, textbooks, articles, journals, magazines, research papers and relevant websites.

\section{Sampling method:-}

The sampling technique used in research is simple Random sampling.

\section{Sample Size:-}

In this research, a sample of 150 employees has to be taken to represent the entire population of 300 . This is the $50.1 \%$ of the entire population taken from the few departments of the organization. So, 150 samples have been taken from the industry for survey and data analysis.

\section{Sample Size Distribution:-}

\begin{tabular}{|c|c|c|}
\hline Level of Management & Total Population & Sample Size \\
\hline Top Level & 30 & 17 \\
\hline Middle Level & 100 & 62 \\
\hline Lower Level & 170 & 71 \\
\hline Total & $\mathbf{3 0 0}$ & $\mathbf{1 5 0}$ \\
\hline
\end{tabular}

\section{Conceptual Framework of training and development of employees:-}

Prior studies and current research based on employee training and development sets a platform that helps to design a model. In this model, there is the existence of correlation between the three drivers of the model i.e. training and development, employee performance and organization performance. The various benefits which are employee received through training leads to employee performance and ultimately lead to organizational performance.

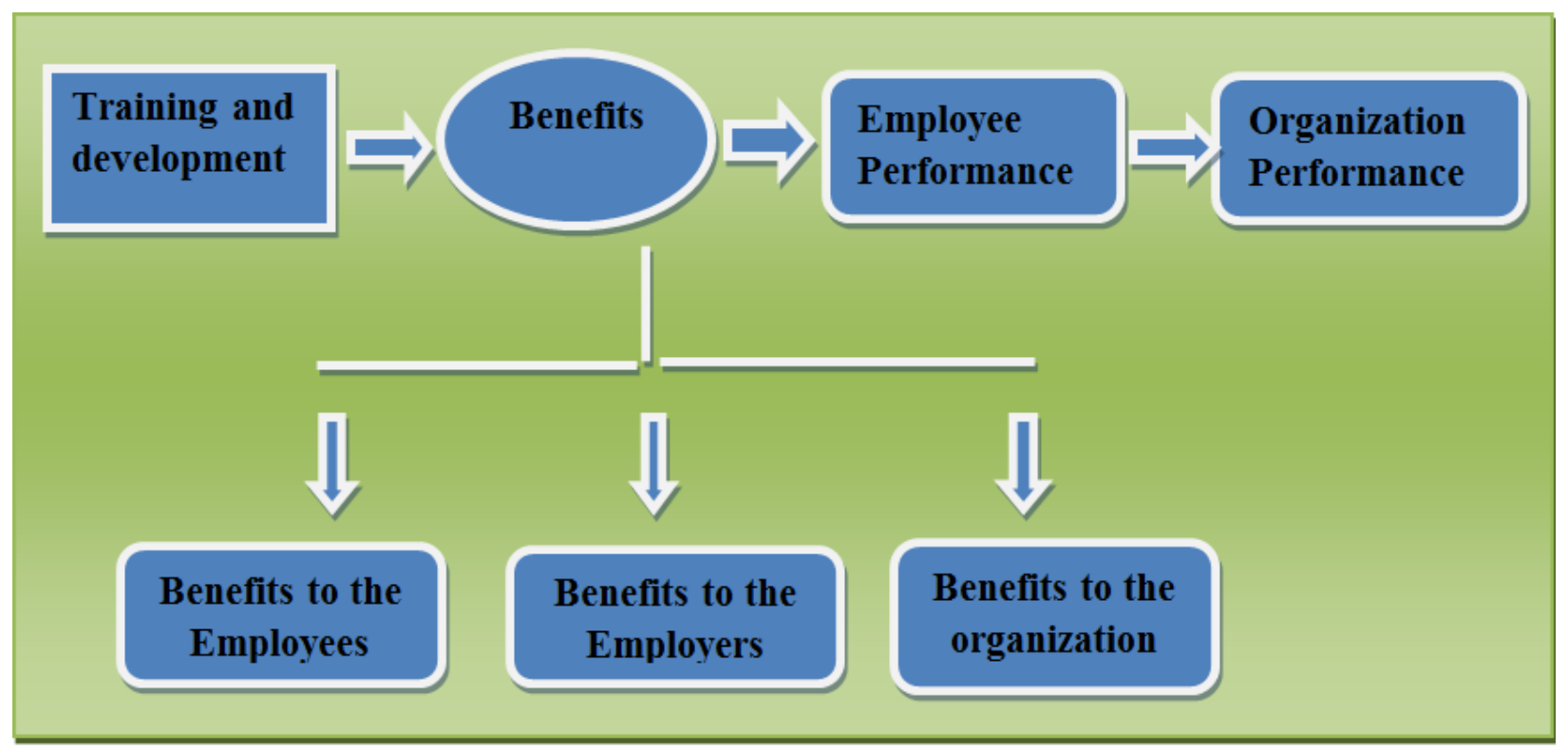

Benefits of Training and Development:-

\begin{tabular}{|c|c|c|}
\hline Benefits to the Employees & Benefits to the Employers & Benefits to the Organization \\
\hline $\begin{array}{l}\text { 1. Career Advancement } \\
\text { 2. Higher Earning } \\
\text { 3. Increased Morale \& } \\
\text { Confidence }\end{array}$ & $\begin{array}{l}\text { 12. Reduction in Supervision } \\
\text { 13. Managerial Development } \\
\text { 14. Ensuring Worker Satisfaction } \\
\text { 15. Economy of Operations }\end{array}$ & $\begin{array}{l}\text { 23. Increased productivity } \\
\text { 24. Updated with latest technology } \\
\text { 25. Enhances organization } \\
\text { reputation and profile }\end{array}$ \\
\hline
\end{tabular}




\begin{tabular}{|l|l|l|}
\hline 4. Improve equipment handling & $\begin{array}{l}\text { 16. Standardization of Procedures } \\
\text { practices }\end{array}$ & $\begin{array}{l}\text { 26. Reduced employee turnover and } \\
\text { absenteeism }\end{array}$ \\
$\begin{array}{l}\text { 5. Maintain safety standards } \\
\text { 6. Development of knowledge, } \\
\text { skill and attitude. }\end{array}$ & $\begin{array}{l}\text { 18. Opportunity for Promotion } \\
\text { 19. Helps in addressing employee } \\
\text { weaknesses }\end{array}$ & $\begin{array}{l}\text { 27. Increased innovation in } \\
\text { strategies and products }\end{array}$ \\
$\begin{array}{l}\text { 7. Friendly work Environment } \\
\text { 8. Develop positive attitude }\end{array}$ & $\begin{array}{l}\text { 20. Keep up with the industrial } \\
\text { changes }\end{array}$ & $\begin{array}{l}\text { Improve organization viability, } \\
\text { scalability and flexibility }\end{array}$ \\
$\begin{array}{l}\text { 9. Team Spirit } \\
\text { 11. Individual Growth }\end{array}$ & $\begin{array}{l}\text { 21. Consistency } \\
\text { 22. Optimum utilization of human } \\
\text { resource }\end{array}$ & $\begin{array}{l}\text { 30. Organization development } \\
\text { 31. Elimination of wastage }\end{array}$ \\
\end{tabular}

Analysis and Findings:-

\begin{tabular}{|c|c|c|c|}
\hline S.NO. & Statements & $\begin{array}{l}\text { Response of the } \\
\text { employees (in \%) }\end{array}$ & Category \\
\hline 1. & T\&D programs are conducted as per the need. & 86 & SA \\
\hline 2. & T\&D programs are well organized. & 62 & ID \\
\hline 3. & $\begin{array}{l}\text { T\&D programs are timely reviewed and } \\
\text { evaluated. }\end{array}$ & 72.5 & $\mathrm{AG}$ \\
\hline 4. & $\begin{array}{l}\text { T\&D enhance the quality and quantity of goods } \\
\text { and services. }\end{array}$ & 86 & SA \\
\hline 5. & $\begin{array}{l}\text { T\&D minimize the chances of accidents and } \\
\text { faulty operations. }\end{array}$ & 70 & ID \\
\hline 6. & $\begin{array}{l}\text { T\&D helps to increase the problem-solving and } \\
\text { decision making ability }\end{array}$ & 79 & A \\
\hline 7. & $\begin{array}{l}\text { T\&D helps to improve the working condition of } \\
\text { the employees. }\end{array}$ & 83 & $\mathrm{SA}$ \\
\hline 8. & $\begin{array}{l}\text { Employees get conceptual as well as theoretical } \\
\text { knowledge from training. }\end{array}$ & 60 & $\mathrm{DA}$ \\
\hline 9. & $\begin{array}{l}\text { T\&D helps to bridge the gap between skilled and } \\
\text { unskilled employees. }\end{array}$ & 75 & $\mathrm{AG}$ \\
\hline 10. & $\begin{array}{l}\text { Employees are encouraged for the training as per } \\
\text { the desired need. }\end{array}$ & 55 & DA \\
\hline 11. & $\begin{array}{l}\text { Positive Interaction between the trainer and the } \\
\text { trainee. }\end{array}$ & 85 & SA \\
\hline 12. & Trainer has a good command over the subject. & 70 & $\mathrm{AG}$ \\
\hline 13. & Environment of the training session is favorable. & 58 & DA \\
\hline 14. & $\begin{array}{l}\text { Training encouraged employees to be committed } \\
\text { towards organizational goals. }\end{array}$ & 75 & $\mathrm{AG}$ \\
\hline 15. & $\begin{array}{l}\text { Set targets are identified and achieved through } \\
\text { training program. }\end{array}$ & 85 & SA \\
\hline 16. & $\begin{array}{l}\text { T\&D programs addresses the strengths and } \\
\text { weaknesses of the employees. }\end{array}$ & 65 & ID \\
\hline 17. & $\begin{array}{l}\text { T\&D helps to enhance the performance of } \\
\text { employees as well as the organization. }\end{array}$ & 90 & SA \\
\hline 18. & T\&D helps to improve the working conditions. & 63.5 & ID \\
\hline 19. & $\begin{array}{l}\text { T\&D helps employees in promotion and other } \\
\text { monetary benefits. }\end{array}$ & 66.5 & ID \\
\hline \multirow[t]{2}{*}{20.} & $\begin{array}{l}\text { T\&D is result-oriented and stabilize the } \\
\text { organization. }\end{array}$ & 71 & $\mathrm{AG}$ \\
\hline & Overall (AMS) & 72.375 & $\mathrm{AG}$ \\
\hline
\end{tabular}

Table No.1:- item wise percentage score and categories of employee's response towards training and development at hero cycles, Ludhiana. SA-strongly agree, AG-agree, ID- indifferent, DA- disagree, SD- strongly disagree 


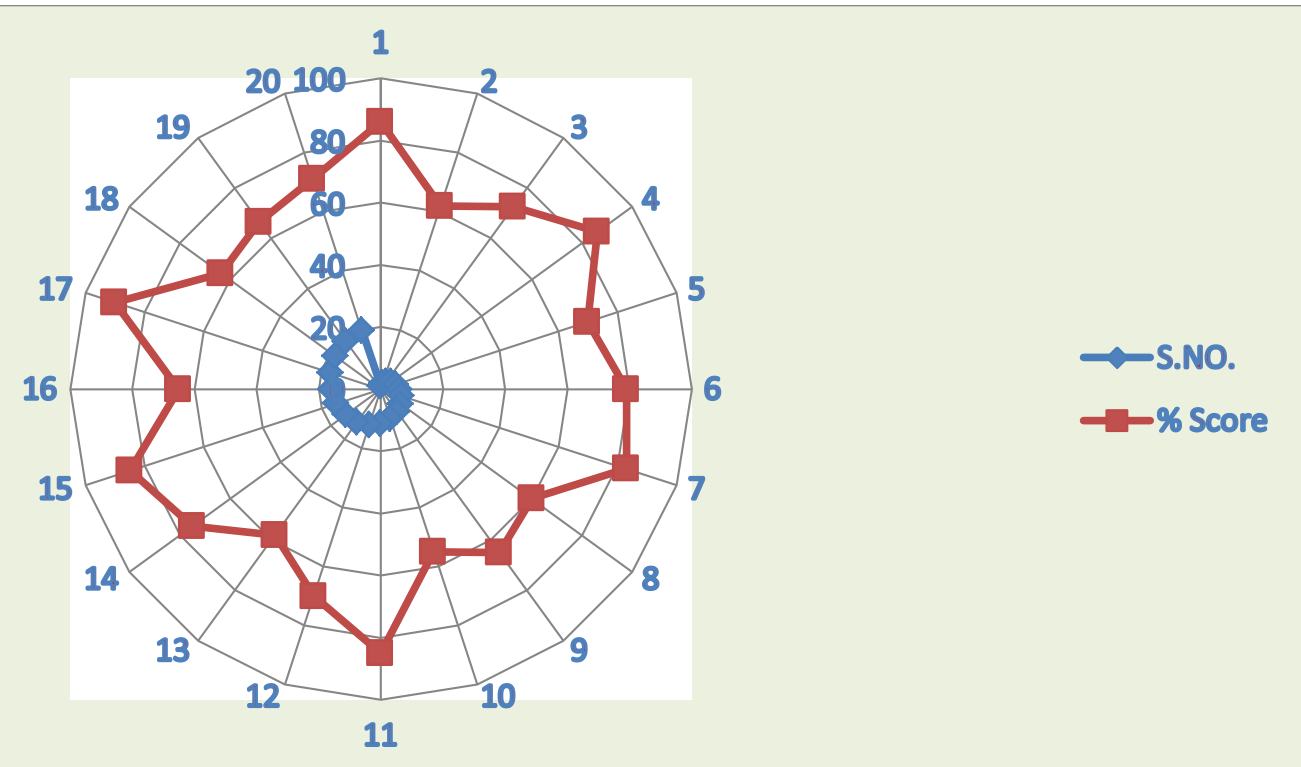

Questionnaire on Training and Development:-

\begin{tabular}{|c|c|c|c|c|c|c|}
\hline S.NO. & Statements & $\begin{array}{l}\text { Strongly } \\
\text { agree (5) }\end{array}$ & $\begin{array}{l}\text { Agree } \\
\text { (4) }\end{array}$ & $\begin{array}{l}\text { Indifferent } \\
\text { (3) }\end{array}$ & $\begin{array}{l}\text { Disagree } \\
\text { (2) }\end{array}$ & $\begin{array}{l}\text { Strongly } \\
\text { disagree } \\
\text { (1) }\end{array}$ \\
\hline 1. & $\begin{array}{l}\text { T\&D programs are conducted as per the } \\
\text { need. }\end{array}$ & & & & & \\
\hline 2. & T\&D programs are well organized. & & & & & \\
\hline 3. & $\begin{array}{l}\text { T\&D programs are timely reviewed and } \\
\text { evaluated. }\end{array}$ & & & & & \\
\hline 4. & $\begin{array}{l}\text { T\&D enhance the quality and quantity of } \\
\text { goods and services. }\end{array}$ & & & & & \\
\hline 5. & $\begin{array}{l}\text { T\&D minimize the chances of accidents } \\
\text { and faulty operations. }\end{array}$ & & & & & \\
\hline 6. & $\begin{array}{l}\text { T\&D helps to increase the problem- } \\
\text { solving and decision making ability }\end{array}$ & & & & & \\
\hline 7. & $\begin{array}{l}\text { T\&D helps to improve the working } \\
\text { condition of the employees. }\end{array}$ & & & & & \\
\hline 8. & $\begin{array}{l}\text { Employees get conceptual as well as } \\
\text { theoretical knowledge from training. }\end{array}$ & & & & & \\
\hline 9. & $\begin{array}{l}\text { T\&D helps to bridge the gap between } \\
\text { skilled and unskilled employees. }\end{array}$ & & & & & \\
\hline 10. & $\begin{array}{l}\text { Employees are encouraged for the } \\
\text { training as per the desired need. }\end{array}$ & & & & & \\
\hline 11. & $\begin{array}{l}\text { Positive Interaction between the trainer } \\
\text { and the trainee. }\end{array}$ & & & & & \\
\hline 12. & $\begin{array}{l}\text { Trainer has a good command over the } \\
\text { subject. }\end{array}$ & & & & & \\
\hline 13. & $\begin{array}{l}\text { Environment of the training session is } \\
\text { favorable. }\end{array}$ & & & & & \\
\hline 14. & $\begin{array}{l}\text { Training encouraged employees to be } \\
\text { committed towards organizational goals. }\end{array}$ & & & & & \\
\hline 15. & $\begin{array}{l}\text { Set targets are identified and achieved } \\
\text { through training program. }\end{array}$ & & & & & \\
\hline 16. & $\begin{array}{l}\text { T\&D programs addresses the strengths } \\
\text { and weaknesses of the employees. }\end{array}$ & & & & & \\
\hline
\end{tabular}




\begin{tabular}{|l|l|l|l|l|l|l|}
\hline $\mathbf{1 7 .}$ & $\begin{array}{l}\text { T\&D helps to enhance the performance } \\
\text { of employees as well as the organization. }\end{array}$ & & & & & \\
\hline $\mathbf{1 8 .}$ & $\begin{array}{l}\text { T\&D helps to improve the working } \\
\text { conditions. }\end{array}$ & & & & & \\
\hline $\mathbf{1 9 .}$ & $\begin{array}{l}\text { T\&D helps employees in promotion and } \\
\text { other monetary benefits. }\end{array}$ & & & & & \\
\hline $\mathbf{2 0 .}$ & $\begin{array}{l}\text { T\&D is result-oriented and stabilize the } \\
\text { organization. }\end{array}$ & & & & & \\
\hline
\end{tabular}

\section{Conclusion:-}

There is a correlation between training and employee performance. The objective of any training program is value addition in the performance of the employees. Training helps employees to achieve their organizational objectives and organization gives a competitive advantage. The training programs conducted in the industry are satisfactory. It helps in enhancing the performance of employee and increase job satisfaction level. This ultimately helps the industry to increase revenue, reduce labor turnover, minimize accidents and improve quality of products and services. The findings of the research showed that the training has a positive impact on both employees as well as the organization. For instance, training develops good communication skills, interpersonal relation, boost the morale of the employees, team work etc.

\section{Recommendations:-}

1. The organization should focus on reward based and result-oriented training strategy.

2. Evaluation of the employees is mandatory after training for obtaining the desired results.

3. Organization should provide more training and development opportunities to their employees in order to reduce the cost of recruiting and hiring new employees.

4. There should be compulsory training program for all employees who address the employee strength and weakness.

5. If training programs are provided timely, they reduce the chances of employee turnover.

6. Training should be used as a tool of group strengthening process.

\section{Limitation of the Study:-}

1. The sample size of the responded was not enough.

2. The respondents were equally divided on the basis of gender but due to lack of female respondents the gender biasness created.

3. Questionnaire is designed as per the target group easily understand it and give responses easily.

4. Perception of the employees varies, so the study is limited to such perceptions expressed by the respondent.

\section{References:-}

1. http://www.herocycles.com/

2. http://www.artofthestart.com/importance-of-training/

3. http://www.nwlink.com/donclark/hrd/history/history2.html

4. https://www.msu.edu/sleightd/trainhst.html

5. https://husys.com/importance-training-development-organizations/

6. Ameeq-ul-Ameeq (2013), "Impact of Training on Employees Development and Performance in Hotel Industry of Lahore, Pakistan”, Journal of Business Studies Quarterly.ISSN2152-1034.

7. Arthur, Bennett, Edens, P.S., and Bell, P.S. (2003). Effectiveness of Training in Organization: A Meta -analysis of Design and Evaluation Features. Journal of Applied Psychology, 88(2), 234-236

8. Aswathappa, K., (2002). Human Resource and Personnel Management. New Delhi: Tata McGraw-Hill Publishing Company Ltd.

9. Bates, Donald L. and Davis, Tammy J. (2010). "The Application Bridge: A Model for Improving Trainee Engagement in the Training Process", International Journal of Management, Vol. 27, No. 3, Part 2, December, pp. 770-776.

10. Goldstein, I. L., and Gessner, M. J. (1988).Training and Development in Work Organizations. International Review of Industrial and Organizational Psychology, 43-72.

11. Oribabor, P.E. (2000). "Human Resources Management, A Strategic Approval" Human Resources Management, 9 (4), pp $21-24$. 
12. Tan, J.A., Hall, R.J., and Boyce, C. (2003), 'The Role of Employee Reactions in Predicting Training,' Human Resource Development Quarterly, Vol. 14, 4, pp. 397-411.

13. KulkarniPallavi P. (2013). A literature review on training \& Development and quality of work life, Researchers World -Journal of Arts, Science \& Commerce E-ISSN 2229-4686 ISSN 2231-4172.

14. Rani, Kavita (2014) "A study on Training and Development in Public Sector Banks", International journal Of Management and Social Science Research, ISSN: 2319-4421.

15. Raja MumtazHussain (2011). “An Empirical study of the relationship between motivation to transfer and transfer of training" Far East Journal of Psychology and Business Vol. 5 No. 1 Far East Research Centre www.fareastjournals.com pp 47-56.

16. Raj Aparna (Second edition, 2013) Training and development, Kalyani Publishers.

17. Roy P. Lynton \&UdaiPareek, Training for Organizational Transformation, Part-2(2000), Sage Publication, N.D.

18. MubasharFarooq and Muhammad Aslam Khan (2011). "Impact of Training and Feedback on Employee Performance" Far East Journal of Psychology and Business Vol. 5 No. 1 pp23-33.

19. Armstrong, M., 2003. A Handbook on Personnel Management Practice. 9th Edt. , London.

20. Falola O.H. (2014), "Effectiveness of Training and Development on Employees Performance and Organization Competitiveness in the Nigerian Banking Industry" Bulletin of the Transilvania University of Brasov. Vol.7 (56) No.1-2014.

21. Singh, Tarun (2015), "Efficacy of Training and Development Programs on Employees Productivity at Bharat Heavy Electricals Limited" International Journal of Allied Practice, Research and Review. Vol. II pp 16-24.

22. Torraco, Richard J., "Early History of the Fields of Practice of Training and Development and Organization Development" (2016).Faculty Publications in Educational Administration. 